\title{
Дизайн архитектурной среды - архитектурная профессия
}

\author{
А.В.Ефимов, МАРХИ, Москва
}

Архитектура прошлого получала «прививки» рационального и художественного свойства, позволяющие ей создавать различные виды сред. Художник Поль Сезанн не разделял в живописи объект и его фон. На языке архитектуры это означает, что нельзя разрывать архитектурный объём и окружающее пространство, которые во взаимодействии приобретают качество архитектурной среды. Течения пластических искусств XX-XXI веков повлияли на развитие дизайна и архитектуры. Существовал механизм перехода от живописи к рельефу, объёму и далее - к объёмно-пространственному окружению.

Архитектура уступила живописи роль лидера нового формообразования. Движение к абстракции стало основной тенденцией эволюции пластических искусств.

В СССР дизайнер исследовал среду, связанную с реальной жизнью людей. В МАРХИ была создана кафедра «Художественное проектирование средовых комплексов», позднее «Дизайн архитектурной среды» (ДАС). Основное направление её деятельности - проектирование архитектурной среды с объектами капитальной и некапитальной архитектуры, комплексного благоустройства, монументально-декоративного искусства, техническими сооружениями в их цветосветовом выражении.

Международный опыт говорит о крепнущем сотрудничестве архитекторов и дизайнеров. Проблема цветосветовой среды города, имеющая двухсотлетнюю историю, за редким исключением пока не осознана отечественными архитекторами, игнорирующими богатый зарубежный опыт перетекания цветовой среды города днём в искусственную световую среду вечером.

В статье приведены примеры формирования городской среды, выполненные студентами кафедры ДАС МАРХИ.

Архитектура и дизайн начали слышать друг друга. Ствол архитектуры существенно укрепился за счёт взаимодействия с дизайном. Это говорит о её потенциальном развитии, что было отмечено Международной комиссией ЮНЕСКО.

Ключевые слова: архитектура, дизайн, пластические искусства, архитектурная среда, идентичность, контекст, цветосветовая среда города, дизайн архитектурной среды.

\section{Architectural Environmental Design - Architectural Profession}

\section{A.V.Efimov, MARKHI, Moscow}

The architecture of the past have been receiving inputs of a rational and artistic nature, allowing it to create different types of environments. The artist Paul Cezanne did not separate the object and its background in his paintings. In the language of architecture, this means that it is impossible to tear apart the architectural objects and the surrounding space, that can acquire the quality of the architectural environment. The trends of the plastic arts of the 20-21st centuries have influenced the development of design and architecture. There was a method of transition from painting to relief, to volume, and further to a three-dimensional environment.

The architecture gave in its role of the leader of the new form design to the painting. Progression towards the abstraction has become the main trend in the evolution of the plastic arts.

In the USSR, the designer studied the environment associated with the reallife of people. The Department of Artistic Design of Environmental Complexes was founded in MARKHI, later named Design of the Architectural Environment Department - DAS. The main direction of its activity is the design of the architectural environment with objects of both permanent and non-permanent architecture, integrated landscaping, monumental and decorative art, technical structures in their color andlight expression.

The international experience points out the intensifying cooperation between architects and designers. The problem of the city's color-lighting environment, which has a twohundred-year-old history, with rare exceptions, has not yet been recognized by domestic architects who ignore the rich foreign experience of overflowing the city's color environment in the afternoon into an artificial light environment in the evening.

The article presents examples of the urban environment formation designed by students of the DAS department of MARKHI. The communication between architecture and design was set. The core of architecture has been significantly strengthened through interaction with design. This indicates its potential development, which was noted by the UNESCO Validation Commission.

Keywords: architecture, design, plastic arts, architectural environment, identity, context, color andlight environment of the city, design of architectural environment.

Когда-то человек обитал в пещерах, в своей доисторической среде. На огромных пространствах Земли возникали очаги примитивного жилища, святилищ, мест совершения обрядов. Это были предвестники архитектуры, которыми человек осваивал пространство, создавая среду жизнеде- 
ятельности. Примитивная архитектура постоянно получала интеллектуальные прививки: с одной стороны, рационально-материалистического свойства (конструкции, материалы, технологии возведения и др.), с другой - подпитывалась духовно (культура, пластические искусства, символика и пр.).

Ствол архитектуры насыщался внутренним пространством и одновременно разветвлялся, проникая в пространство внешнее. Способность архитектуры осваивать пространство постоянно увеличивалась, архитектура создавала различные виды сред - жилую, общественную, промышленную и др. Сегодня этот процесс актуализируется.

Искусство архитектуры пришло в Россию из Франции и Италии, стран, с которыми всегда существовало культурное взаимодействие, российская знать говорила по-французски. Страна испытывала также и англосаксонское, более рациональное инженерное влияние, которое распространялось на науку, экономику и другие сферы [1].

XX век продемонстрировал различного рода проникновения художественного начала в инженерное и наоборот. Художники и архитекторы активно взаимодействовали, правда, не всегда бесконфликтно.

Немецкий архитектор Вальтер Гропиус, основавший знаменитый Баухауз, пригласил в качестве профессоров ведущих художников лирической абстракции Василия Кандинского и Пауля Клее, которые внесли свою романтическую ноту в традиционно инженерную деятельность архитектурного учебного заведения. Однако, когда пост руководителя Баухауза последовательно занимали Ханнес Мейер и Людвиг Миес ван дер Роэ, эти художники подвергались критике за то, что «живут в башне из слоновой кости», как бы вне окружающей реальности. Здесь налицо два взгляда на архитектуру: первый представляет её как материально-художественное явление, второй изолирует её от художественного влияния.

Предтеча искусства модернизма - французский художник Поль Сезанн - никогда не разделял в живописи элементы изображаемой реальности: объект и его фон, представляя их как единое живописное целое, формирущее пластику визуального образа.

Эта установка Сезанна на языке архитектуры означает, что нельзя разрывать архитектурный массив и окружающее пространство, которые в некотором балансе способны приобретать качество архитектурной среды. Конкретные соотношения массы и пространства диктуются функцией места, взаимоотношениями обитателей, их культурными традициями и определяют «дух места» (genios loci - лат.). При этом существуют различные виды проникновения пространства в массив, определяющие его «пористость», и виды освоения пространства материальными объектами, определяющие меру его «материальной насыщенности».

Течения пластических искусств XX-XXI веков в общей эволюции мирового художественного поля решительно повлияли на дизайн, архитектуру. Картина развития пластических искусств этого периода позволяет утверждать, что существовал, например, механизм перехода от цвета на плоскости (живопись) через крупную фактуру коллажа к рельефу, обладающему третьим измерением, далее - к объёму, трёхмерной форме, оторвавшейся от плоскости (скульптура) - к сочетанию объёмных форм в пространстве (инсталляция, дизайн, архитектура) и далее к объёмно-пространственному окружению (природной, урбанистической ткани и их сочетанию). При этом, разумеется, средовые формы искусства, оказывая влияние друг на друга, сохраняют свою самостоятельность [2].

Творческий путь Александра Веснина («основателя конструктивизма», по оценке Ле Корбюзье) подтверждает эту закономерность. Поначалу А. Веснин - автор беспредметных композиций. Живопись кубизма и футуризма начала XX века спровоцировала его на создание системы конструктивизма со своей логикой формообразования. Первоначальный этап развития конструктивизма получил название «от изображения к конструкции». Концепция конструктивизма дала огромный толчок развитию всевозможных форм дизайнерского творчества - конструированию предметно-пространственной среды, а также архитектуре, которая подтверждает зрелость каждого стиля, воплощая его в реальном объёмно-пространственном выражении.

В 1919-1920 годах А. Веснин создал ряд сценографий в московских театрах. Макетируя театральные установки, он не порывал с живописью и цветом. Его театральные работы были началом «революции» в осмыслении роли художника театра. Разрушив традиционный павильон сценической коробки, он открыл безграничные возможности для развёртывания событий во времени и пространстве. Вместе с Всеволодом Мейерхольдом и Любовью Поповой А. Веснин был автором проекта грандиозного «массового действа» «Борьба и победа» на Ходынском поле в Москве - попытки вывести театральное зрелище в городское пространство и создать тематическую праздничную среду.

Архитектура - «мать искусств» - в течение многих веков порождала искусства и одновременно поддерживалась живописью, скульптурой, гобеленом, витражом, мозаикой. Но в XX веке именно живопись приняла на себя роль лидера нового формообразования и со временем существенно преобразила архитектуру. Живопись модернизма неумолимо смещала вектор своего действия от изображения элементов реальности к созданию самоценных произведений без ссылок на реальность. За живописью тем же путём последовала и скульптура, что стало своего рода трамплином для развития дизайна и архитектуры. Движение к абстракции - основная тенденция эволюции пластических искусств прошлого века. Скульптура и предметный дизайн исторически первыми принимали эстафету достижений абстрактной живописи и материализовали их. Каждую новую волну художественного движения замыкала архитектура. Однако обусловленная инженерно-техническими возможностями своего времени, она отставала в реализации новых идей. Проекты архитекторов, 
созданные на волне достижений художников, находили порой своё воплощение спустя многие годы, а то и вовсе оставались на бумаге. Воплощение пространственных объектов дизайна и архитектуры, вдохновлённых пластическими идеями живописи, было отягощено утилитарными требованиями [3].

В какой степени и как именно достижения пластических искусств - модернизма, затем постмодернизма, а также эпохи технологических достижений конца XX - начала XXI века, нашли выражение в архитектурном творчестве?

Искусство модерна, усвоившего в своей колористике и формообразовании природные мотивы, перенесло в архитектуру своё понимание цвета и пластики (рис. 1), которое позднее, сформулированное в терминах органического искусства, получило масштабное развитие в мировой архитектуры в середине XX столетия. Экспрессионистская живопись и скульптура «сообщили» архитектуре исключительную выразительность форм (рис. 2) и эхом отозвались в искусстве абстрактного экспрессионизма через половину столетия (рис. 3).

Кубизм, ставивший перед собой задачу исследования структуры формы, нашёл выражение в новой пластике чешского архитектурного кубизма (рис. 4), а футуризм, провозгласивший своей первоосновой движение, соответственно воплотил его в динамике архитектуры итальянского футуризма (см. рисунок на 2-й странице обложки). Геометрическая абстракция супрематизма и неопластицизма, практически в неизменном виде была усвоена в России и Голландии (рис. 5). В то же время колористические конструкторские эксперименты русских авангардистов нашли непосредственное выражение в архитектуре конструктивизма (рис. 6), рационализма и, конечно, - деконструктивизма (рис. 7). С другой стороны, живопись и пластика поп-арта почти буквально перенесли свою изобразительность в декор архитектуры постмодернизма, унаследовавшей конкретные цвета и формы произведений поп-культуры (рис. 8).

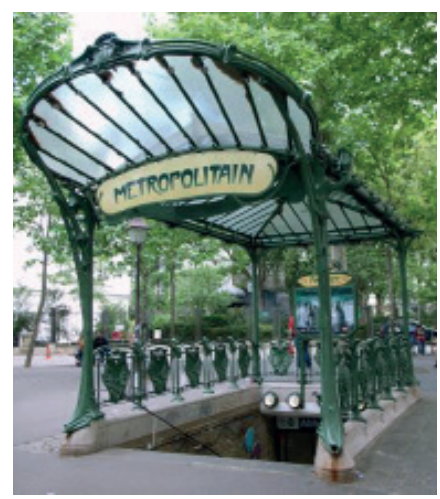

Рис. 1. Павильон парижского метро. Архитектор Г. Гимар. 1900 год (источник: http:// www.callimmo.fr/images/CALL/ bg-header-home-4.jpg)

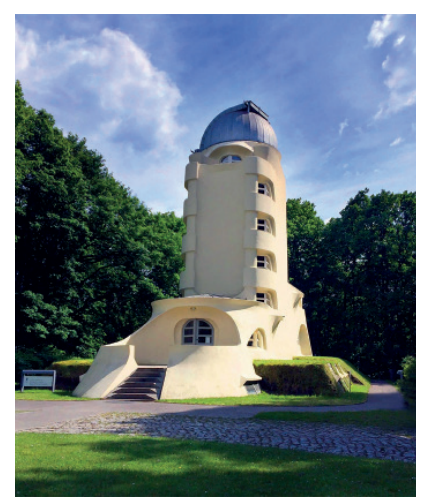

Рис. 2. Башня Эйнштейна. Потсдам. Архитектор Э. Мендельсон. 1924 год (источник: https://www.archinfo.sk/imagehandler/42115/2490486/ gallery/box_61030/orig_1/2. jpg)
Архитектура хай-тека выразилась преимущественно в минималистских формах и металлических цветах своих безупречно рациональных построений, утвердив эстетику, противоположную органической. Информационные технологии конца XX - начала XXI века, открывшие путь дигитального искусства, позволили радикально расширить возможности архитектурного творчества, воочию представить новые фантастические замыслы архитекторов в виртуальном пространстве.

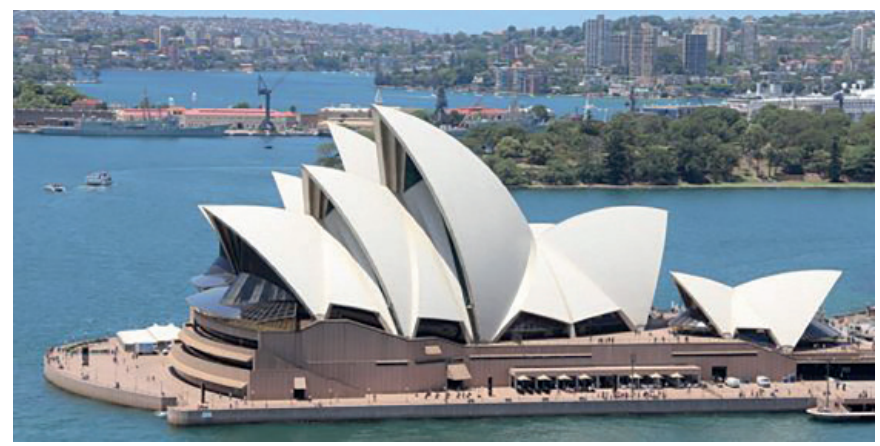

Рис. 3. Оперный театр в Сиднее. Архитектор Й. Утцон. 1959-1973 годы (источник: https://style.nv.ua/img/forall) users/270/27032/sydney-opera-719780_1920.jpg)

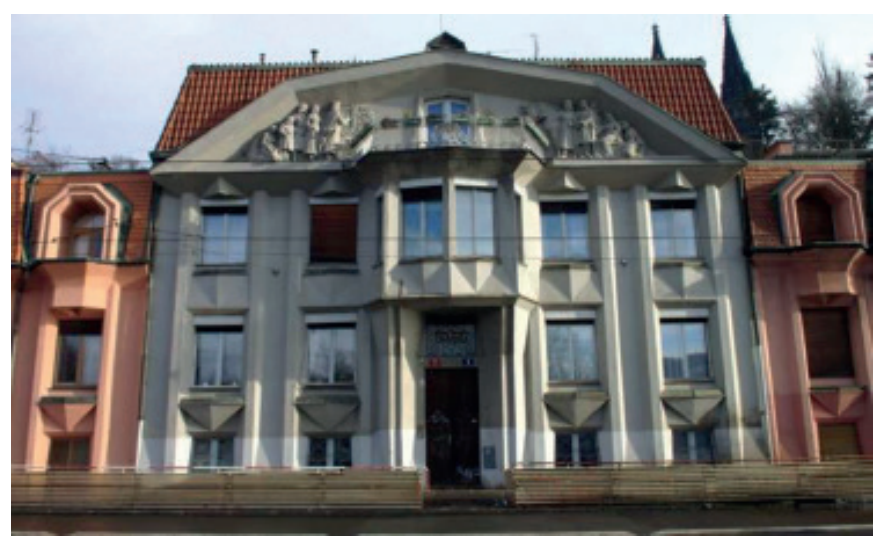

Рис. 4. Тройной дом. Архитектор Й. Хохол. 1912-1913 годы (источник: https://iloveprg.ru/wp-content/uploads/2014/02/ troynoy-dom7.jpg)
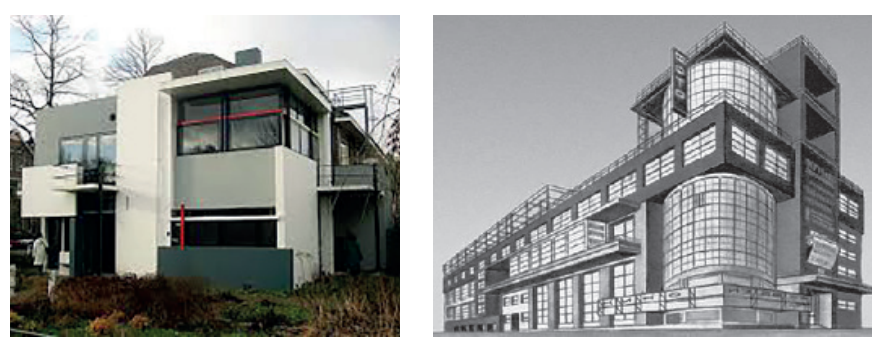

Pис. 5. Дом Шрёдера в Рис. 6. Проект Дома культуУтрехте. Архитектор Г. ры им. Зуева. Архитектор И. Ритвельд. 1924 год (ис- Голосов. 1927-1929 годы (источник: https://farm4. точник: http://prezentacii.info/ staticflickr.com/3039/2553 wp-content/uploads/2015/11/01 571979_31d855df79_o.jpg) 30U8I9YiVl86ss/24.jpg). 
Обращение к историческом архитектурному наследию, следование историческим стилям и местным традициям - непрерывающаяся линия в архитектуре многих регионов мира, постоянно пульсирующая, как воспоминания об архитектуре прошедших времён и цивилизаций [4].

Появление в России «производственного искусства» киоски, фонари, мебель, плакат - впоследствии названного Селимом Хан-Магомедовым «дизайном», заняло родственную архитектуре нишу, что провоцировало создание новой

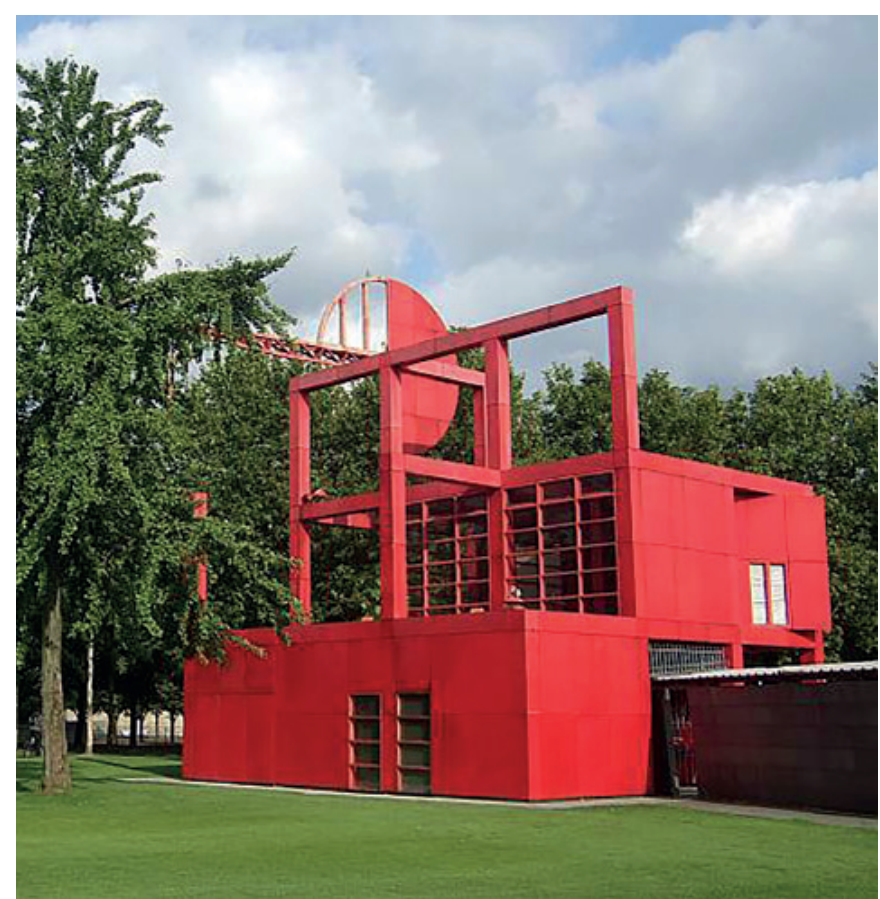

Puс. 7. Фолли для парка Ля Вилетт. Архитектор Б. Чуми. Париж. 2005 год (источник: http://parisweb.ru/wp-content) uploads/2012/07/Folies.jpg)

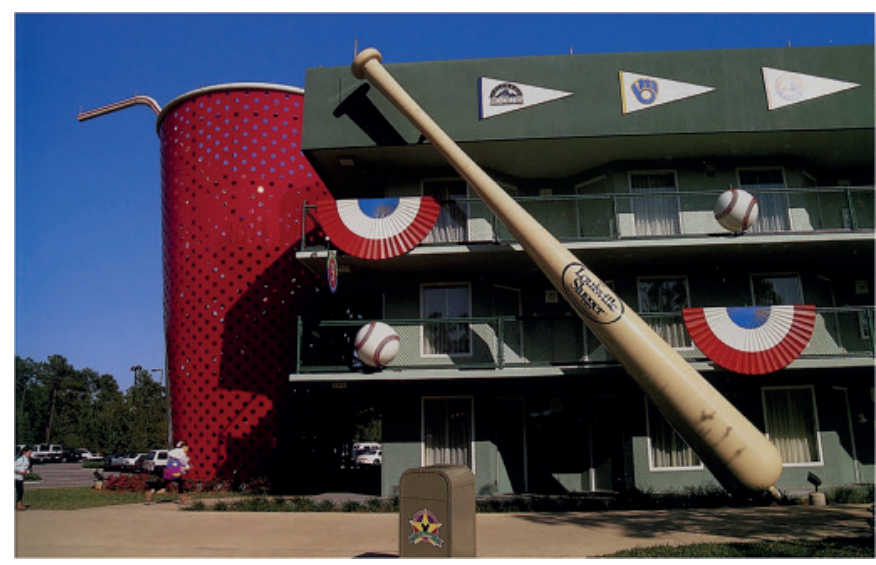

Puc. 8. Гостиница «Дисней'С Олл-Стар Cпортс Резорт» («Disney's All-Star Sports Resort») Дисней-парк. Флорида. 1995 год. архитектуры, более подвижной и пространственной. Однако это влияние было довольно быстро аннулировано и, следуя «указаниям сверху» приняло идеологию «освоения архитектурного наследия».

Второе пришествие дизайна в СССР оказалось более впечатляющим, поскольку директор ВНИИ технической эстетики Юрий Соловьев, который работал под патронатом Государственного комитета по науке и технике и был известен в дизайнерской элите мира, основал Союз дизайнеров. Эта деятельность имела масштабный характер: во всех союзных республиках были созданы дизайн-центры, работу которых координировал ВНИИТЭ. Появилась профессия дизайнера, которая стала заниматься проблемами архитектурной среды, до которых обычно не доходили руки архитекторов. Дизайнерская активность стала заметно обогащать эту среду. При этом дизайнеры опирались на современное пластическое искусство, воплотившееся в многогранных проявлениях стрит-арта.

Итальянский художник, дизайнер, архитектор, теоретик проектной культуры Этторе Соттсасе в одной из статей в «Домусе» (1962) утверждал, что «дизайн имеет дело... со средой, с культурной атмосферой, в которую погружен объект». Этой же логике он следовал и в своих архитектурных работах, выполненных в 1980-1990-х годах в Италии, Японии, США, Китае и др. «Архитектура - это создание искусственного пространства [среды. - А.Е.], и когда вы попадаете в него, вы начинаете плакать» [5].

Средовая тематика, о которой шли споры в 1970-х годах, во многом обязана сотрудникам ЦНИИТИА, Сенежской студии Союза художников СССР, Институту генерального плана г. Москвы и многим архитекторам-энтузиастам, среди которых Алексей Гутнов, Вячеслав Глазычев, Владимир Аронов, Андрей Боков и др. Одним из практических итогов «средового движения» стала новая редакция образа московской улицы Старый Арбат (руководитель А. Гутнов). Автором этих строк параллельно было выполнено формирование колористической среды этой улицы с учётом нового прочтения её исторической полихромии в сложившемся контексте центральной части Москвы.

В Москве и других городах бурлила деятельность художников - оформителей крупных выставочных пространств, их дизайн позиционировался как художественное явление, имеющее явно средовую направленность. В этой деятельности впервые проявился интерес к средовой идентичности, к культурному и пространственному контексту. Средовые пространства - общественные и личные, открытые и закрытые - всегда связаны и обусловлены некими процессами и событиями, поэтому разработка, к примеру, средовых маршрутов, была связана с реальной жизнью людей, их интересами, передвижениями, особенностями общения.

С ростом городов в мире актуализировалась проблема формирования городской среды, возникла необходимость проектирования средовых комплексов, а соответственно - необ- 
ходимость предпроектных исследований, в том числе изучение контекста будущего объекта - историко-культурного, функционального, пространственно-пластического и т.д. К тому же появились новые технологические возможности исследований, проектирования и строительства. Возникли контуры новой архитектурной профессии, объединяющей архитектуру и дизайн.

В 1988 году заместитель директора ВНИИТЭ Георгий Минервин организовал в Московском архитектурном институте кафедру «Художественное проектирование средовых комплексов», на которую с большим подозрением смотрели многие преподаватели и студенты: «Дизайн - это что, лавки и скамейки?» Конечно, не было никаких сомнений в главенстве архитектуры, но архитектурная среда ещё не была достаточно осмыслена. Со временем кафедра получила более определённое название - «Дизайн архитектурной среды» - и с тех пор была нацелена на проектирование городской среды и среды крупных общественных интерьеров. Средовой подход стал методологической основой средового проектирования. Кафедра начала подготовку специалистов архитектурно-средового профиля.

Деятельность средового архитектора в мировой практике архитектурного образования определяется терминами «Environmental design» (англ.) и «Design de milieu d'architecture» (франц.). В нашей стране этим терминам соответствует «Дизайн архитектурной среды» - «ДАС».

С годами все более очевидным становится понимание архитектуры как обширной области человеческой деятельности, обеспечивающей многогранные жизненные процессы современного человека. Подобно медицине, включающей множество направлений, архитектура также стремится к дифференциации при одновременном сохранении целостности. Сегодня ясно выделился ряд направлений: архитектура зданий и сооружений, градостроительство, реконструкция и реставрация памятников архитектуры, ландшафтная архитектура, дизайн архитектурной среды.

Первое значение термина «design» - проект, проектирование. Наименование направления - дизайн архитектурной среды - означает проектирование архитектурной среды, прежде всего городской, с включёнными в неё объектами архитектуры, «зелёной архитектуры», объектами комплексного благоустройства, монументально-декоративного искусства, техническими сооружениями. Помимо этого, объектом проектирования архитектора-дизайнера становятся интерьеры транспортно-пересадочных узлов, торговых моллов, экспозиционных пространств и др. Обширные городские пространства, созданные архитектурой и её колористическими и световыми преобразованиями, являют собой динамично пульсирующую средовую реальность, в которую погружён человек и с которой работает архитектор-дизайнер.

Мы живём в материальном окружении, созданном, главным образом, предыдущими поколениями, но постоянно стремимся к его переустройству, построению новой среды как с точки зрения информации и функции, так и эстетики. Но, как показывает жизнь, эстетическая сторона этого процесса большей частью игнорируется, что обусловлено приоритетом решения социально-функциональных задач, а также слабой ориентацией архитектора в области пластической культуры. В отечественных архитектурных школах традиционно делается упор на освоение «изобразительных» дисциплин, в то время как создание новой

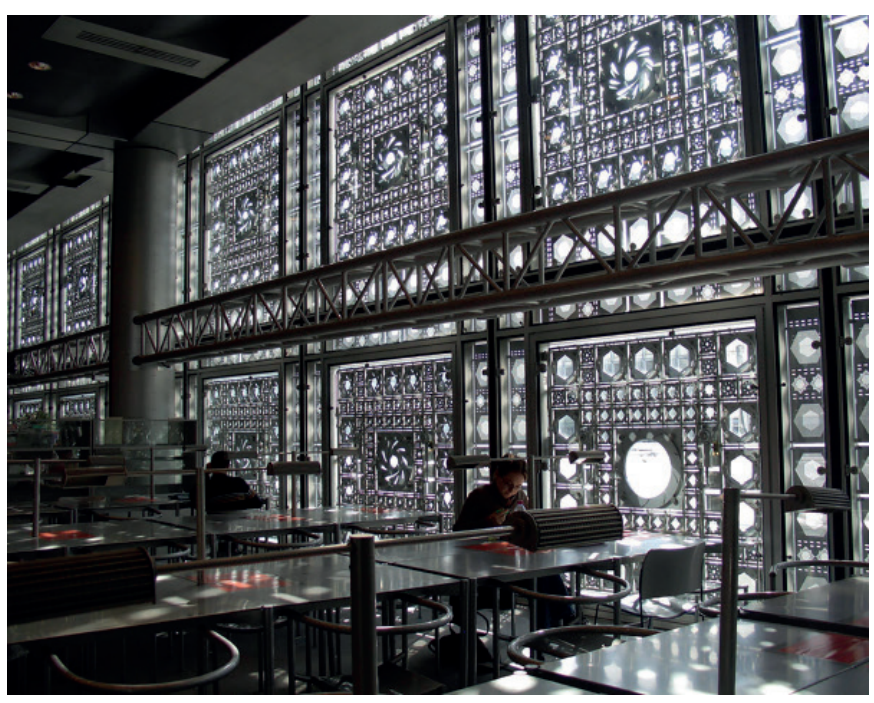

Рис. 9. Институт арабского мира. Архитектор Жан Нувель. Париж. 1987 год (источник: https://avatars.mds.yandex.net) get-pdb/33827/e63c8f64-dd3b-4f58-b937-b80993c81c1b/ s1200?webp=false)
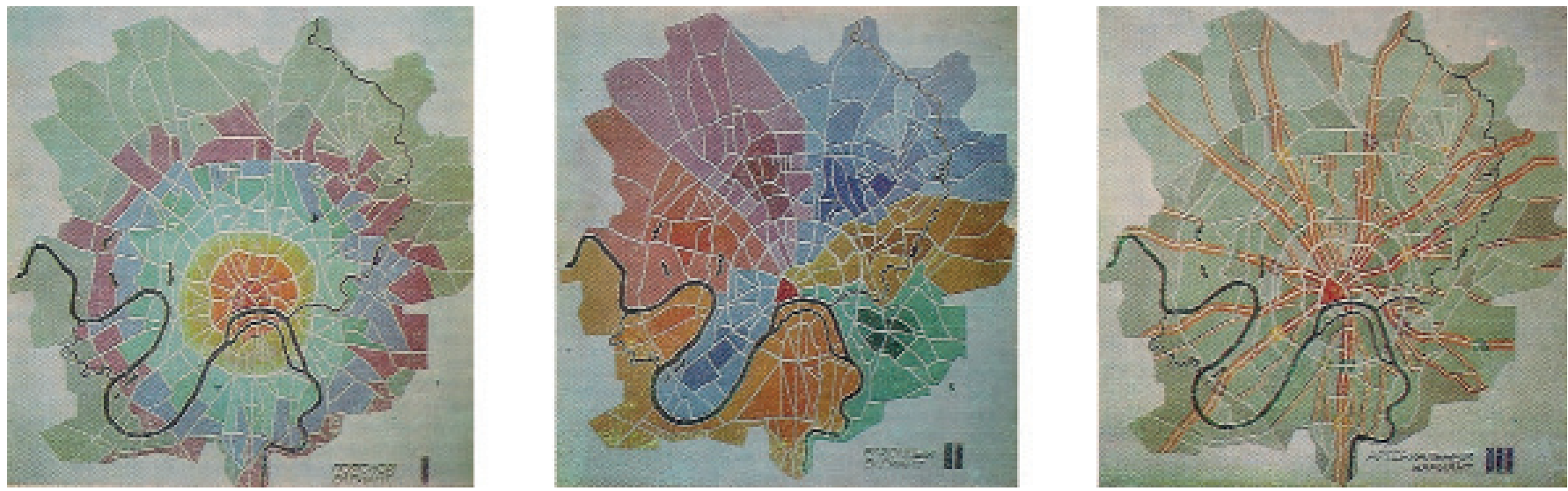

Рис. 10. Проект плановой наружной окраски Москвы 1929 года. Автор проекта - Л. Антакольский 
архитектурной среды требует от профессионалов солидной подготовки не столько изобразительной, сколько пространственно-пластической и аналитико-фантазийной, позволяющей ему выработать профессиональный язык, адекватный нашему времени. Поэтому направление ДАС ввело изучение таких художественных дисциплин, как графика, пластика, колористика, светодизайн, которые являются средствами поиска проектных решений и одновременно достижения художественно-образной выразительности средовых объектов.

Две профессии - архитектура и дизайн, когда-то существовавшие относительно самостоятельно, протянули друг другу руки, потому что уже давно испытывали взаимно существующее притяжение. Архитектор пытался быть дизайнером, дизайнер - архитектором. $0 б$ этом говорит международный опыт архитектурно-дизайнерской деятельности. Архитекторы Ренцо Пьяно и Ричард Роджерс, представители двух разных культур - французской и английской, соединились в общем «высказывании» - Центр Помпиду в Париже. Поначалу жители французской столицы не приняли образ Центра. Всем известны классические архитектурные ансамбли Парижа, впитавшие традиции нескольких веков. Центр Помпиду возмутил парижан, они назвали постройку «нефтеперегонным заводом». Однако со временем этот объект всё же был признан парижанами. Этому во многом способствовало появление возле Центра пространственной игровой формы - Фонтана Стравинского, который создали Жан Тэнгли и Ника де Санфаль как общественное пространство, соединившее традиционное с авангардным.

В здании Института арабского мира в Париже (архитектор Жан Нувель), имеющем лаконичную форму параллелепипеда, обращает на себя внимание решение главного фасада в виде чёткого горизонтального прямоугольника. Рационально-жёсткая структура фасада таит в каждой своей ячейке некоторую интригу: за внешней стеклянной поверхностью помещены диафрагмы, подобные тем, что находятся в объективах фотоаппаратов. При ярком свете диафрагма сжимается, оставляя свету лишь небольшое отверстие, а при слабом - максимально открывается. Фасад обеспечивает режим оптимальной освещённости интерьера, он становится подвижной дизайнерской формой, в результате - архитектура «дышит» (рис. 9).

Латинский мир считает архитектуру и дизайн явлениями художественной культуры, а англосаксонский - преимущественно инженерной, считает Андрей Боков [1], что по сути означает необходимость их творческой встречи и позволяет считать их потенциальными участниками создания окружающей человека среды как комплексного многоаспектного явления. Разумеется, в конкретных проявлениях этой среды могут преобладать как интуитивно-художественные, так и рационально-инженерные начала.

Мировая практика показывает, что исчезают принципиальные разграничения архитектурной и дизайнерской деятельности. В архитектурных мастерских работают дизайнеры, а в дизайнерских - архитекторы. Кто из них создаёт вечные произведения искусства, а кто - дизайнерский продукт, сказать невозможно. И если силой энергии медиа какие-то дизайнерские опусы выносятся на поверхность, то эта технология уже подхвачена архитектурой. Дизайн как более энергичное и динамичное явление, связанное с крупным бизнесом, во многом подсказывает архитектуре правила выживания.

Жан Нувель создал башню «Акбар» в Барселоне. В процессе проектирования он сотрудничал со светодизайнером Яном Керсале, который отвечал за вечерний образ сооружения. В отличие от отечественной практики, разделяющей архитектурное проектирование и «дизайнерские штучки», оба автора координировали свои действия. На фасаде грандиозной сигаровидной башни, доминирующей в значительной части города, предполагалось с наступлением тёмного времени суток включать неоновые трубки на откосах окон, располагающихся в ритмическом порядке. Они создавали светящийся полихромный узор, отсылающий к истокам североафриканского искусства. Эта идея была воплощена после коррекции пластики архитектуры фасада. Трубки не просто крепились к фасаду, а были спрятаны в небольшие ниши-углубления возле оконных проёмов, так что зритель видел не прямой свет, а излучение из самого тела башни. Это был общий успех архитектора и светодизайнера.

Сотрудничество подобного рода состоялось и в Абу-Даби (ОАЭ), где протяжённый мост принимал динамический светоцветовой образ с наступлением темноты. Архитектор Заха Хадид создала его вместе с голландским светодизайнером Рогиром ван дер Хейде.

Следует отметить феномен цветосветовой среды города, традиционно игнорируемый российскими архитекторами. Цвет и свет близки генетически, днём человек более склонен видеть хроматические отношения, а ночью - светотональные, что обусловлено физиологией зрения. Перетекание цветового окружения в световое - динамика цветосветовой среды, с которой человек сверяет существование во времени и свой эмоциональный тонус. Если цветовые характеристики архитектурных объектов годами хранят своё постоянство, то световые могут моментально радикально меняться, создавая порой непредсказуемые образы материальных объектов и окружения.

Цветовая среда города, создаваемая архитектурными, природными и другими объектами, произведениями пластических искусств - колористика города - выполняет историкокультурную, функциональную и художественно-эстетическую функции. Она может целенаправленно формироваться, о чём свидетельствует опыт истории.

B конце XVIII века Екатерина II утвердила генеральные планы двухсот российских городов, а Александр I в 1814 году издал Указ об окраске зданий в Петербурге, Москве и других городах в мягкие пастельные цвета. Курьеры с образцами цветов скакали по городам Российской империи вплоть до Иркутска, осуществляя цветовой контроль архитектуры. Такого масштабного преображения колористической среды городов не знала ни одна страна в мире.

В 1929 году члены Ассоциации новых архитекторов (АСНОВА) разработали «Проект плановой окраски Москвы», 
опирающийся на её генеральный план (рис. 10). Проект включал три варианта: кольцевой, районный и артериальный. Однако в связи с экономическими трудностями проекту не суждено было реализоваться. И все же идея формирования колористики города на основе генерального плана открыла большие перспективы колористического совершенствования для многих городов [6].

В 1980 году группа колористов под руководством архитектора Джованни Бруно разработала «Регулярный план полихромии Турина» (рис. 11), основанный на достоверных исторических материалах, в частности, прекрасного «Туринского жёлтого». Полихромия города использовала принцип «гибкого одноцветия», создавая яркую узнаваемость.

Эта инициатива, единственная по своему характеру и масштабам как для Италии, так возможно, и для всего мира. За три года было окрашено более двух тысяч зданий, продемонстрирована эффективность системы, не оставляющей мест для произвольных решений. Восстанавливая цветовые облики Турина, специалисты осуществили крупномасштабные цветовые мероприятия, позволяющие преодолеть фрагментарность реставрации, определяемую случайностью заказа.

Туринская группа осуществила также аналогичные проекты в городах Джулианова в Абруции, Кофманвола, Кавальер-Маджоре и Ванчетта. Эта работа дала начало волне ренессанса исторической цветовой среды других итальянских городов [7].

В конце XX века для Москвы была разработана концепция колористики на основе исторических цветовых палитр XVIIXX веков. Покраска зданий регламентировалась Паспортами колористического решения, что способствовало воссозданию исторической цветовой атмосферы архитектурного тела центральной части города и одновременно созданию своеобразной колористики новых жилых образований.

Для полноценного функционирования городской среды в тёмное время суток был разработан световой генплан города, опиравшийся на градостроительный каркас и его узлы. Вначале проектировалась световая среда центра и вылетных магистралей. Общая программа предусматривала архитектурно-художественного освещения десятков административных зданий, вокзалов, храмов и других объектов. Цветовым разнообразием искусственного освещения были выделены транспортные магистрали, жилые зоны, общественные пространства и парковые территории. Специально разрабатывались концепции архитектурного освещения крупных жилых районов на периферии города, которые служили основой световых решений отдельных зданий.

После реализации этих программ вечерняя среда Москвы резко преобразилась, по уровню света она превзошла Париж и Лондон. Однако некоторая переосвещённость заставила вспомнить «эффект чистого неба», когда на небе видны звезды. Качественно новым явлением стали крупные праздничные световые шоу, которые заставили по-новому звучать общественные пространства и традиционные места встреч москвичей. Светодизайн по-новому представлял историческую архитектуру, соответствовал новому пульсу жизни города, новому пониманию городской среды [8]. Крупные архитектурные объекты и их комплексы заявили о себе колористикой в дневное время, а в вечернее и ночное время, когда город особенно нуждался в навигационных средствах и новом ощущении пространства, светодизайн проявил их.

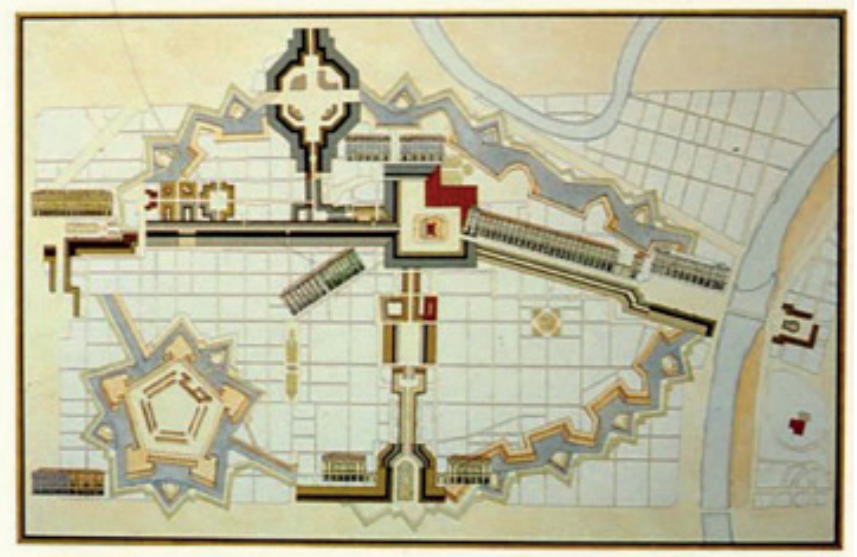

Рис. 11. Регулярный план полихромии Турина. Автор проекта - Дж. Брино. 1980 год

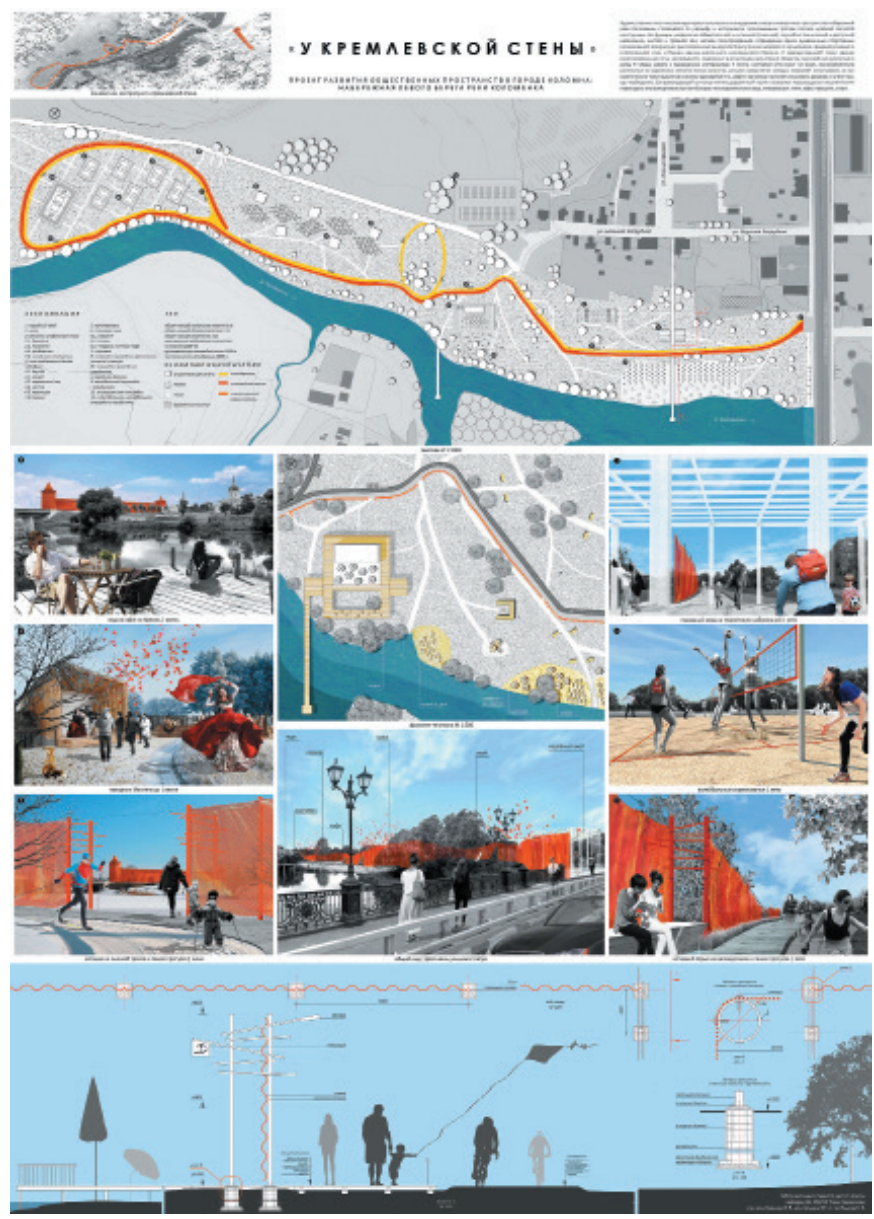

Рис. 12. Развитие общественных пространств в Коломне. Автор проекта Э. Парамонова. 2016 год 
Видимые элементы инфраструктуры города обычно проявляются в городской среде в виде благоустройства. В конце 1990-х комплексное благоустройство Москвы, помимо своих традиционных составляющих, включало колористику зданий и их архитектурное освещение, что существенно повышало средовую ценность городского пространства. Однако впоследствии цвет и свет были исключены из этого комплекса, и благоустройство города стало априори неполноценным.
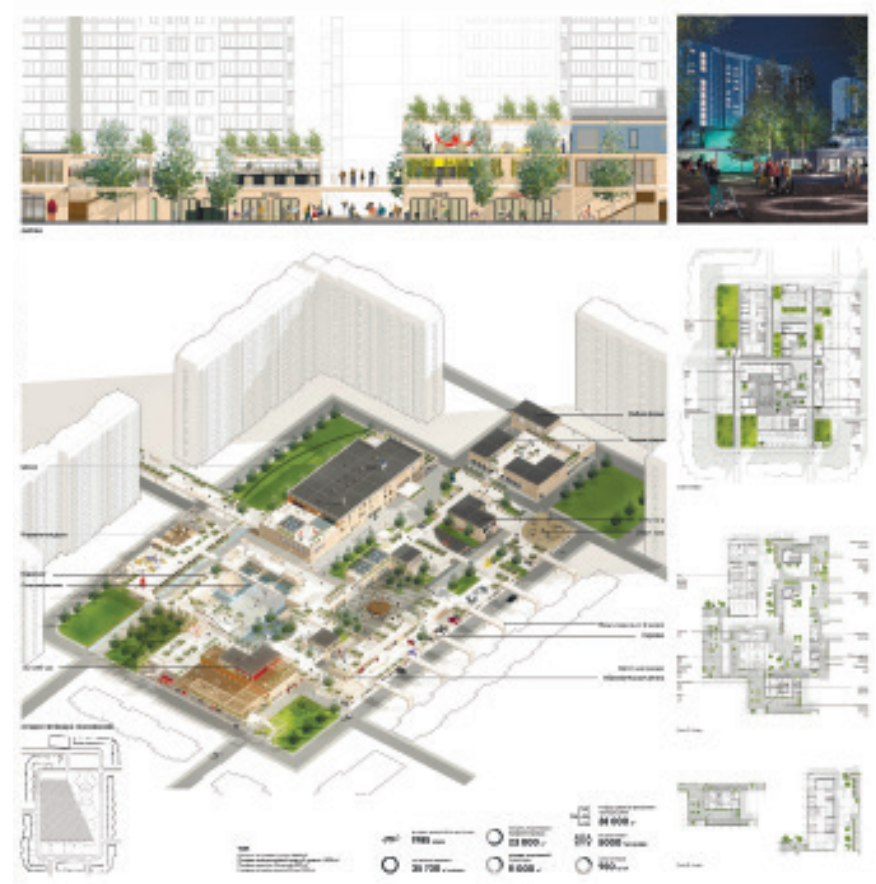

Рис. 13. Формирование дворового общественного пространства. Автор проекта А. Гришина. 2018 год

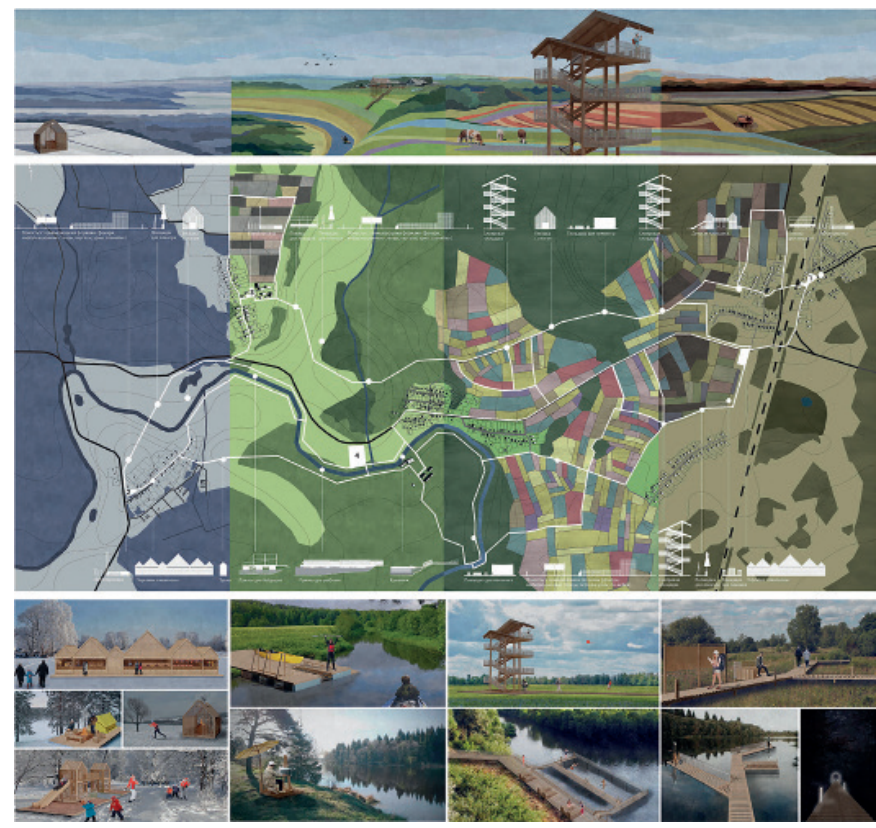

Рис. 14. Система туристических маршрутов «Шаляпинские тропы». Автор проекта Ю. Калдина. 2018 год
Примеры работ студентов кафедры ДАС МАРХИ

Проект студентки третьего курса Э. Парамоновой «Развитие общественных пространств в Коломне» (руководители - доц. В.В. Савинкин, доц. В.Г. Кузьмин, ст. преп. К.В. Янькова. 2016/17 учебный год) (рис. 12).

Художественно-пластическая идея проекта была основана на внедрённой в пространство набережной реки Коломенки полосы красной сетчатой конструкции, которая своим цветом отвечает краснокирпичному цвету стен и башен Коломенского кремля и разделяет разные функциональные зоны территории. С художественной точки зрения спроектированная стена отсылает к инсталляциям скульптора Христо Явашева, масштабным работам Ричарда Серра и Ричарда Лонга. Сетчатая структура висит на тросе, последовательно растянутом на сдвоенных металлических колоннах, рисунок соединения которых позволяет использовать их как осветительно-навигационную систему. Эффект занавеса помогает устраивать разрывы в стене там, где это необходимо. Сопровождающий сетчатую линию деревянный настил позволяет посетителям парка последовательно перемещаться вдоль его функциональных зон.

Дипломный проект выпускницы бакалавриата А. Гришиной «Формирование дворового общественного пространства» (микрорайон «Люберецкие поля». Некрасовка; руководитель проф. 0.Р. Мамлеев. 2017/18 учебный год) (рис. 13).

В проекте предпринята попытка создания общественных пространств в спальных районах для комфортной и полноценной жизни. Предпроектный анализ вскрывает основные проблемы спальных районов, рассматриваются наименее комфортные для жизни территории Москвы. Предлагаются возможные пути решения данных проблем. Основная идея проекта - создание модульной структуры, которая в зависимости от местоположения имеет разную форму, размер и высотность и выполняет необходимые для конкретного места функции.

В качестве места проектирования выбран двор одного из районов Новой Москвы - Некрасовки, микрорайон «Люберецкие поля», который входит в тройку худших районов Москвы. Проект двора предусматривает создание сложной двух- и трёхуровневой структуры, в которой размещаются школа, детский сад, спортивный центр, образовательные кружки, библиотека, магазины, кафе, кинотеатр, парковка. Второй уровень - эксплуатируемый, на нём располагаются детские и спортивные зоны, места тихо отдыха, скейт-парк и городские огороды. Вся территория активно озеленяется деревьями, кустарниками, лианами и травами, создающими ощущение парка.

Дипломный проект бакалавра Ю. Калдиной «Система туристических маршрутов «Шаляпинские тропы» (Ростовский район. Ярославская область; руководители - проф. М.А. Соколова, доц. Г.А. Соболев, доц. М.А. Силкина. 2017/18 учебный год) (рис. 14).

Проект включает систему тематических средовых маршрутов, связанных с проявлением исторической компоненты 
забытых мест. Деревню Охотино в Ростовском районе Ярославской области и соседнюю деревню Ратухино в конце XIX - начале XX века соединяла тропа, которой пользовались К. Коровин, Ф. Шаляпин и их друзья, любившие отдыхать в этих местах. Проект предусматривает организацию систем маршрутов, их оборудование специальными объектами - малой архитектурой и временными строениями. Это открытые, изготовленные из традиционных материалов архитектурные формы, соответствующие «духу места», проявляющие его пластический эквивалент. Они ненавязчиво вписаны в ландшафт и оснащены техническими средствами. Простые и выразительные, лёгкие и долговечные, экономичные и быстро возводимые формы сомасштабны человеку.

В системе туристических маршрутов выделены особо значимые пункты: дача-музей К. Коровина с небольшим амфитеатром для проведения фестивалей, пристанционная площадь станции Итлярь, конеферма Любильцево, туристический центр с семейными домиками для отдыха, столовая, спортивные и детские площадки, тренажёрный и концертный залы.

Когда-то борьба с излишествами в архитектуре подписала приговор архитектору-художнику, бывшему главным лицом и в архитектурном проекте, и на стройке. Пришедший ему на смену инженер «с архитектурными амбициями» не привёл страну к новой архитектуре, он свёл её к массовому примитивизму. Этому способствовало и насильственное забвение советского архитектурного авангарда. Сегодня профессия архитектора отнесена к техническим специальностям в классификации ВАК. Считается, что архитектор-педагог, например, помимо своей прямой деятельности поддерживает свой профессиональный авторитет научными статьями, а постройки или творческие выставки не учитываются. Особо приветствуются публикации на английском языке в международной базе данных. И тогда он подтверждает свой профессиональный уровень. Архитектора нехотя привлекает крупный застройщик, и менеджер выжимает из него максимум квадратных метров, игнорируя художественные потуги зодчего.

Однако мировой опыт показывает, что архитектура и дизайн начали слышать друг друга, перенимать необходимые черты: архитектура - мгновенность дизайнерской реакции на требования времени, использование новых технологий, а дизайн - понимание идентичности сложившейся среды и опоры на культурно-ценностный потенциал общества.

Создание архитектурно-средовых объектов и их комплексов отличается единовременным воздействием на этот процесс таких проектных сфер, как инженерное творчество и пластические искусства, средовой дизайн и эргономика, экология, световой дизайн и колористика, социология, фундаментальные и прикладные науки и т.д. В отличие от архитектора, создающего локальные объекты, архитектор-дизайнер связывает многочисленный мир материальных объектов в единое цивилизационное

1 Заключение комиссии ЮНЕСКО и Международного союза архитекторов о деятельности Московского архитектурного института. 2017 год. поле среды жизнедеятельности. Эти пересекающиеся потоки, представляющие смежные стороны современной проектной культуры, включают множество профессий и направлений. Современные проектировщики архитектурной среды должны одинаково успешно ориентироваться как в комплексе новейших научно-технических достижений, так и в художественно-эстетической проблематике архитектуры и дизайна.

Перечень профессий, связанных с деятельностью архитектора-дизайнера, охватывает следующие виды: архитектор-дизайнер в области урбанистики, архитектор-дизайнер по перепрофилированию средовых комплексов, архитектордизайнер городской среды, архитектор-дизайнер интерьеров зданий и сооружений, архитектор-цветодизайнер, архитектор-светодизайнер. Ствол архитектуры существенно крепнет за счёт развития этих её новых ветвей. Неизмеримо возрастает потенциальная способность архитектуры генерировать различные средовые образования, улучшать таким образом качество жизни людей.

Комиссия ЮНЕСКО и Международного союза архитекторов, аккредитовавшая МАРХИ в 2017 году, была впечатлена работой кафедры ДАС, «которая сосредоточена на эмпирических и феноменологических проблемах в архитектуре... эта работа представляет собой совершенно другую сторону архитектурного мышления МАРХИ, обладающую потенциалом для развития» ${ }^{1}$.

Надежда общества связывается с профессиональной способностью архитектора-дизайнера видеть город целиком и стратегически определять места благополучных и деградирующих территорий, их потенциальных реконструкций или реноваций, то есть мест первоочередных преобразований среды города, опираясь на его «социально-пространственный каркас» и его «ткань», а также на его способность ощущать и фиксировать идентичность и историю места, его наполнение - «плазму», как средство его материально-пространственного и художественного осмысления на основе новой эстетики.

Именно эту комплексную проблему призван решать архитектор-дизайнер - специалист в области проектирования архитектурной среды.

\section{Лuтература}

1. Боков, А.В. Коллеги - соперники: архитектура и дизайн в России / А.В. Боков // Academia. Архитектура и строительство. - 2018. - № 3. - С. 5-12. DOI 10.22337/20779038-2018-3-5-12

2. Ефимов, А.В. Цвет + Форма. Искусство 20-21 веков. Живопись. Скульптура. Инсталляция. Лэнд-арт. Дигитал-арт / А.В. Ефимов. - М. : БуксМарт, 2014. - 616 с. ISBN: 978-5906190-14-7

3. Ефимов, А.В. Архитектурная колористика и пластические искусства / А.В. Ефимов, Н.Г. Панова. - М. : БуксМарт, 2018. - 424 c. ISBN: 978-5-607043-00-8

4. Steele, J. Architecture Today / J. Steele. - New York : Phaidon Press Inc., 1997. 
5. Ettore, Sottsass. Architect and Designer / Ettore Sottsass. - Los Angeles : Los Angeles County Museum of Art. Merrell Publishers, 2006.

6. Ефимов, А.В. Колористика города / А.В. Ефимов. - М. : Стройиздат, 1990.

7. Brino, G. Il Piano del Colore di Torino (1979-1980) / G. Brino. - Casabella 476/477. - P. 59-60

8. Щепетков, Н.И. Световой дизайн города : учебное пособие / Н.И. Щепетков. - М. : Архитектура-С, 2006. - 320 с. ISBN: 5-9647-0103-5

\section{References}

1. Bokov A.V. Kollegi - soperniki: arkhitektura i dizain v Rossii [Colleagues - rivals: architecture and design in Russia]. Academia. Arkhitektura i stroitel'stvo [Academia. Architecture and Construction], 2018, no. 3, pp. 5-12. DOI 10.22337/2077-90382018-3-5-12. (In Russ., abstr. in Engl.).
2. Efimov A.V. TsVET + FORMA. Iskusstvo 20-21 vekov. Zhivopis'. Skul'ptura. Installyatsiya. Lend-art. Digital-art [Color + Shape. Art of 20-21 centuries. Painting. Sculpture. Installation Land art. Digital art]. Moscow, BuksMart Publ., 2014. (In Russ.)

3. Efimov A.V., Panova N.G. Arkhitekturnaya koloristika i plasticheskie iskusstva [Architectural Coloring and Plastic Arts]. Moscow, BuksMart Publ., 2018. (In Russ.)

4. Steele J. Architecture Today. New York: Phaidon Press Inc., 1997. (In Engl.)

5. Ettore Sottsass. Architect and Designer. Los Angeles: Los Angeles County Museum of Art. Merrell Publishers, 2006. (In Engl.)

6. Efimov A.V. Koloristika goroda [City coloring]. Moscow, Stroiizdat Publ., 1990. (In Russ.)

7. Brino G. Il Piano del Colore di Torino (1979-1980). Casabella 476/477., pp. 59-60

8. Shchepetkov N.I. Svetovoi dizain goroda [Lighting design of the city]. Moscow, Arkhitektura-S Publ., 2006.

Ефимов Андрей Владимирович (Москва). Доктор архитектуры, профессор, почётный член Российской академии художеств. Заведующий кафедрой дизайна архитектурной среды ФГБОУ ВО «Московский архитектурный института (государственная академия ) (107031, Москва, ул. Рождественка, 11/4. МАРХИ).

Efimov Andrey Vladimirovich (Moscow). Doctor of Architecture, Professor, Honorary Member of the Russian Academy of Arts. Head of the Department of the Architectural Environment Design at Moscow Architectural Institute (State Academy) (11/4 Rozhdestvenka st, Moscow, 107031. MARCHI). 